\section{Field and laboratory assessments of sugarcane mutants selected in vitro for resistance to im- azapyr herbicide}

\author{
RS Rutherford ${ }^{1,2}$, KZ Maphalala ${ }^{1,2}$, AC Koch ${ }^{1,2}$, SJ Snyman ${ }^{1,2}$ and \\ MP Watt ${ }^{1^{*}}$
}

\begin{abstract}
Seven imazapyr-tolerant mutant sugarcane plants, previously generated by in vitro mutagenesis, were studied. The imazapyr concentrations required to inhibit their acetolactate synthase (ALS basal activity) (IC ${ }_{50}$ as $\mu$ moles acetoin $\mathrm{h}^{-1} \mathrm{mg}^{-1}$ protein) were $0.77-5.36$ times greater than that of the N12 'parent'. The basal ALS activities of Mut1 and Mut6 were 1.4-fold higher than that of N12. When the mutants were sprayed with Arsenal ${ }^{\circ}$ GEN 2 (312 and 624 g a.i. imazapyr ha-1), 2 months after field planting, and evaluated 9 months later, live stalk height and number were significantly lowest in Mut2, Mut3 and the control N12. No differences in sucrose, fibre and estimated yield were observed amongst lines in untreated plots. Mutant plants germinated and grew in soil treated with the herbicide (at the lethal dose of $1248 \mathrm{~g}$ a.i. ha- ${ }^{-1}$ ). The Mut lines tested in this study offer improved options for weed control.
\end{abstract}

Key words: Acetolactate synthase, ethyl methanesulfonate, imidazolinone, mutation breeding.

\section{INTRODUCTION}

Weeds can drastically reduce cane and sugar yields (Millhollon 1992). The application of herbicides is therefore a well-established necessity and is most crucial during plant cane establishment and subsequent ratoon crop regeneration (Campbell 2008). Herbicides must be carefully selected and applied as they disrupt essential processes (e.g. photosynthesis, amino acid biosynthesis) shared by crops and weeds. In sugarcane, this is especially difficult, as a many of the weeds are also graminaceous species, e.g. Cynodon dactylon and Digitaria longifolia (Campbell 2008).

One approach to herbicide phytotoxicity is the development of cultivars resistant to broad-spectrum herbicides. In sugarcane, as in most crops, this can be achieved by conventional plant breeding, genetic transformation (Leibbrandt and Snyman 2003) and induced mutagenesis (Rutherford et al. 2014). Because of the lengthy plant breeding and selection process in sugarcane, legislative restrictions, licensing costs and public opposition to transgenesis, our preferred approach is the generation of herbicide-resistant variants of proven elite genotypes using mutagenesis. Hence, cultivar N12 was selected for generating variants resistant to the herbicide imazapyr (Koch et al. 2012). N12 is known to be hardy (McIntyre and Nuss 1998) and is a favored cultivar of emerging small-scale farmers in South Africa, who operate under
Crop Breeding and Applied Biotechnology 17: 107-114, 2017 Brazilian Society of Plant Breeding. Printed in Brazil http://dx.doi.org/10.1590/198470332017v17n2a17 
low input conditions, on predominantly strongly acid $(\mathrm{pH}<5)$ soils, with weed pressure as a major production constraint (Cockburn et al. 2012).

The active ingredient imazapyr, an imidazolinone (IMI) compound, is registered in South Africa [no. L8817; Arsenal ${ }^{\circ}$ GEN 2; BASF South Africa (Pty) Ltd] for the control of grass and broadleaf weeds prior to sugarcane re-planting. Imidazolinone herbicides are active against the enzyme acetolactate synthase (ALS; EC 2.2.1.6), also known as acetohydroxyacid synthase (AHAS; EC 4.1.3.18), which catalyses the first step in the biosynthesis of isoleucine, leucine and valine.

Seven putatively imazapyr-resistant sugarcane mutant plants (Mut1-Mut7) were generated from N12 by callus exposure to $16 \mathrm{mM}$ ethyl methanesulfonate, and selection on imazapyr-containing medium (Koch et al. 2012). This report describes subsequent studies on these mutants grown in the field addressing their imazapyr resistance, basal activity of the ALS enzyme and the imazapyr concentration required to inhibit it by $50 \%\left(\mathrm{IC}_{50}\right)$, and plant characteristics and yield, compared with the 'parent' N12.

The mutant genotypes were also tested for their tolerance to the persistent herbicide residual activity in the soil. For other crops (Santos et al. 2014), and as per herbicide label instructions, a 4-month waiting period and at least 600 $\mathrm{mm}$ of precipitation are necessary before planting to avoid suppression of sugarcane sett germination and growth. However, the ability to replant during the herbicide soil residual period would afford the sugarcane farmer improved weed control, as the crop would attain full canopy before any significant weed pressure. Setts of the mutant genotypes were, therefore, also tested for germination and growth shortly after the soil was sprayed with imazapyr.

\section{MATERIAL AND METHODS}

\section{Plant material, field trials and imazapyr application}

The Mut1-7 obtained by Koch et al. (2012) and N12 control plants were bulked-up in vitro (Ramgareeb et al. 2010). After 3 months (30 - $40 \mathrm{~cm}$ in height), they were planted in field areas A, B and C. Stalks from 11-month-old plants from area A were cut into 3-budded setts and planted in area D. The field (lat 29 $42^{\prime} 24.5585^{\prime \prime} \mathrm{S}$, long $31^{\circ} 02^{\prime} 45.1735$ $E^{\prime \prime}$; long-term mean annual rainfall $1023 \mathrm{~mm}$ ) was divided into four areas (A-D); A, B and C were subdivided into three replicated plots ( 1 × $3.5 \mathrm{~m}$ row, 10 plants per row) in a randomized complete block design. Two months after planting (4-6 leaf stage), Arsenal ${ }^{\circ}$ GEN 2 [240 g a.i. ha-1 ${ }^{-1}$ imazapyr; BASF, Ago BV Arnhem, Switzerland] was applied directly over the top of the plants at 312 and $624 \mathrm{~g}$ a.i. ha ${ }^{-1}$ in areas $B$ and C, i.e. $1 / 4$ and $1 / 2$ of the lethal dose, with a gas-regulated sprayer and flat-fan nozzle (Albuz APE $110^{\circ}$ ) at $194.2 \mathrm{I} \mathrm{ha}^{-1}$ and $1.515 \mathrm{I} \mathrm{min} \mathrm{m}^{-1}$. Area A was unsprayed. Area D was halved $\left(8 \times 9.5 \mathrm{~m}\right.$ each) and the soil of one half was treated with Arsenal ${ }^{\circ} \mathrm{GEN} 2$ at $1248 \mathrm{~g}$ a.i. ha ${ }^{-1}$ (lethal dose), 3 weeks prior to planting. Both halves were planted with 3-budded setts from mutant (Mut1-Mut7) and N12 control plants, as 90 100 buds per $9.5 \mathrm{~m}$. Rainfall was $78 \mathrm{~mm}$ between herbicide application and planting. Germination (per genotype in the treated section as \% germination in the corresponding untreated one) was determined after 3 weeks and shoot length after 12 weeks.

\section{Yield component and quality of field-grown plants}

Stalk number per plot and stalk height and diameter were determined (on 20 randomly chosen stalks per plot) for mutant and N12 plants in areas A, B and C, 11 months after planting. Estimated cane yield was calculated by $\mathrm{ndpr}^{2} \mathrm{~L} / 1000$ (Miller and James 1974, Gravois et al. 1991); where: $\mathrm{n}=$ number of stalks.plot ${ }^{-1} ; \mathrm{d}=$ density at $1.00 \mathrm{~g} \mathrm{~cm}^{-3} ; \mathrm{r}=$ stalk radius $(\mathrm{cm})$ (radius was calculated from the diameter divided by 2$) ; L=$ stalk height $(\mathrm{cm})$.

In addition, the plants in the unsprayed area A were cut back and allowed to re-grow (ratoon) to maturity, and assessed again for yield. Sucrose and fiber contents were analyzed in a mill room of the South African Sugarcane Research Institute (SASRI) (Schoonees-Muir et al. 2009). All data were analyzed using a One-way ANOVA and Holm-Sidak test $(P<0.05)$. 


\section{Acetolactate synthase enzyme and IC ${ }_{50}$ determinations}

Leaf ALS enzyme activity ( $\mu \mathrm{mol}$ acetoin $\mathrm{h}^{-1} \mathrm{mg}^{-1}$ protein) was determined colorimetrically (530 $\mathrm{nm}$ ) by acetoin formed (Yu et al. 2010, Koch et al. 2012) and total protein the method of Bradford (1976).

The concentration of imazapyr required to inhibit ALS activity by $50 \%\left(I_{50}\right)$ was determined for the third leaf of Mut1Mut7 and control N12 from plot A, 5 months after planting. The fresh leaf mass to obtain a maximized initial absorbance at $530 \mathrm{~nm}$ for acetoin at $0 \mu \mathrm{M}$ imazapyr was established per genotype, to correct for basal activity differences. The ALS activity was assayed with 0 - $30 \mu \mathrm{M}$ imazapyr [PESTANAL ${ }^{\circledR}$ (Sigma-Aldrich)]. The $\mathrm{IC}_{50}$ values were calculated from the nonlinear regression analysis of log (inhibitor) vs. response (GraphPad Prism 5.0., GraphPad Software Inc., San Diego, CA, USA). Comparisons of plant IC $\mathrm{C}_{50}$ values were performed using a One-way analysis of variance (ANOVA) and HolmSidak test $(P<0.05)$. Field imazapyr resistance levels in Mut1, Mut6 and N12 control plants were evaluated by ALS assays at 1 and 3,6 , and 12 weeks after imazapyr spraying.

\section{RESULTS AND DISCUSSION}

\section{ALS activities and the effect of imazapyr on the enzyme and yield components}

The basal ALS activities of Mut1-Mut7 lines and N12 control plants were determined 2 months after planting and prior to herbicide spraying. Mut1 and Mut6 plants had significantly higher ALS activities (190.4 and 179.0 $\mu$ moles acetoin $\mathrm{h}^{-1} \mathrm{mg}^{-1}$ protein, respectively) than control N12 (1.48 and 1.39 times that of N12, respectively) and the other mutants (Table 1). Mutants exhibited 0.77 - 5.36 times greater $\mathrm{IC}_{50}$ than N12 (Figure 1). The $\mathrm{IC}_{50}$ value of Mut1 was significantly higher than those of Mut2 and control N12; no other significant differences were recorded. By way of comparison, two commercially released imidazolinone-resistant rice mutants have been shown to exhibit $I_{50}$ values of 13 and 369 times greater than non-mutant rice (Avila et al. 2005). These rice mutants were considered tolerant and resistant, respectively.

After 2 months in the field, plants were sprayed with 0, 312 and $624 \mathrm{~g}$ a.i. imazapyr ha-1 (areas A, B and C, respectively). Six weeks later, all plants in the untreated area had normal green leaves (Figure 2a), as did those of Mut1, Mut4, Mut5, Mut6, and Mut7 in the sprayed areas B and C. However, the leaves of Mut2, Mut3 and control N12 turned reddish-brown with accumulated 3-deoxyanthocyanidin luteolinidin (spectral identification not shown) (Figure $2 \mathrm{~b}$ and $\mathrm{c}$ ), a symptom of IMI herbicide phytotoxicity (Tan et al. 2006). Nine months after herbicide application, only a few Mut2 and Mut3 plants in the $312 \mathrm{~g}$ a.i. ha-1 treatment were alive; all of the N12, Mut2 and Mut3 plants sprayed with $624 \mathrm{~g}$ a.i. ha ${ }^{-1}$ imazapyr had died.

Mut1 and Mut6 were further investigated for their responses to imazapyr over 12 weeks (Figure 3). In the untreated area A, ALS activities were significantly higher $(P<0.001)$ than that of control N12 at week 12 (Figure 3a).
Table 1. Basal ALS activities of mutant (Mut1-Mut7) and control N12 plants. a-b indicate statistically significant differences among genotypes

\begin{tabular}{cc}
\hline Genotype & ALS activity ( $\mu$ moles acetoin $\mathbf{h}^{-1} \mathbf{~ m}^{-1}$ protein) \\
\hline Mut1 & $190.4 \pm 10.3^{\mathrm{b}}$ \\
Mut2 & $120.3 \pm 4.7^{\mathrm{a}}$ \\
Mut3 & $138.4 \pm 11.5^{\mathrm{a}}$ \\
Mut4 & $111.4 \pm 4.2^{\mathrm{a}}$ \\
Mut5 & $128.4 \pm 10.7^{\mathrm{a}}$ \\
Mut6 & $179.0 \pm 6.9^{\mathrm{b}}$ \\
Mut7 & $136.9 \pm 5.0^{\mathrm{a}}$ \\
N12 & $128.8 \pm 3.8^{\mathrm{a}}$ \\
\hline
\end{tabular}

One-way ANOVA and Holm-Sidak test, $P<0.05 ; \mathrm{n}=12$, mean $\pm \mathrm{SE}$

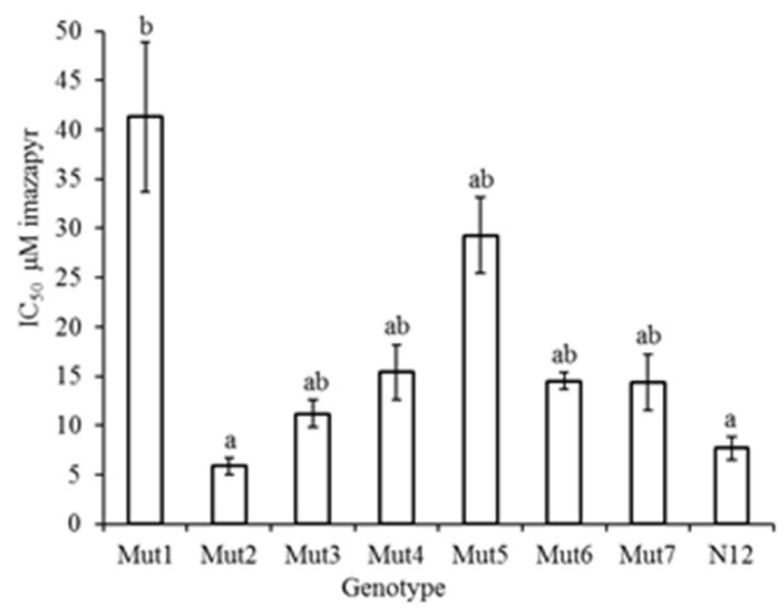

Figure 1. $I C_{50}$ values as a measure of imazapyr resistance in mutant sugarcane genotypes. Plants were tested for ALS activity 5 months after planting. $a-b$ indicate statistically significant differences amongst genotypes. One-way ANOVA and Holm-Sidak test, $\mathrm{P}<$ $0.05 ; n=3$, mean $\pm S E$. For analysis, data were $\log _{10}$-transformed; untransformed data are presented. 


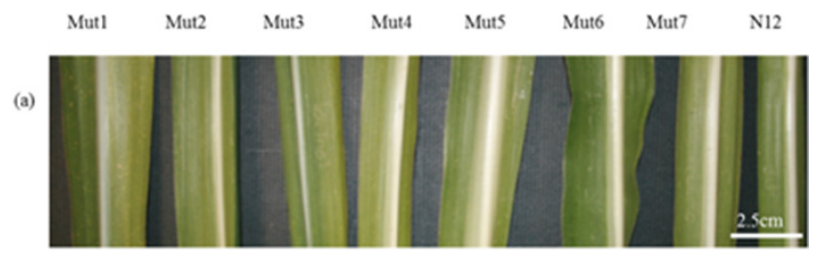

(b)

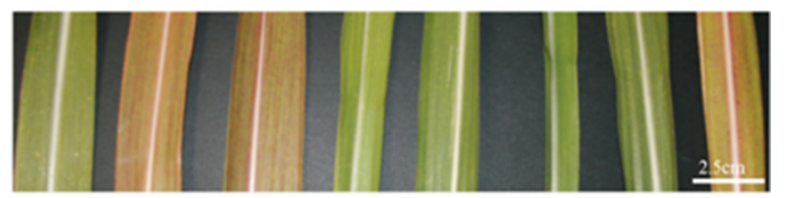

(c)

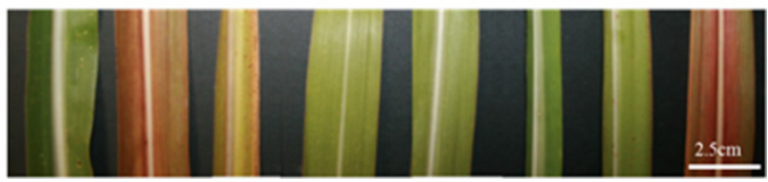

Figure 2. The effect of imazapyr on leaf appearance of plants Mut1-Mut7 and control N12 6 weeks after foliar application. Leaves were collected from (a) untreated; (b) $312 \mathrm{~g}$ a.i. ha ${ }^{-1}$; and (c) $624 \mathrm{~g}$ a.i. ha-1 sprayed areas.

There was a small depression in ALS activity for Mut1 and Mut6 plants at week 6, but an increase at week 12. Over time, there were no significant differences in ALS activity between Mut1 and Mut6 plants, and the ALS activity in N12 control plants decreased significantly. In the treated areas B and C (312 and $624 \mathrm{~g}$ a.i. ha ${ }^{-1}$, respectively) (Figures $3 \mathrm{~b}$ and $\mathrm{c}$ ), the ALS activity for the Mut1 and Mut6 plants at week 6 was significantly lower $(P<0.001)$ than that of the unsprayed plants (Figure 3a). The N12 control plants displayed decreased ALS activities at weeks 3, 6 and 12 in the $624 \mathrm{~g}$ a.i. ha ${ }^{-1}$ area. These were significantly lower $(P<0.001)$ than those in corresponding weeks in the untreated area. Sprayed Mut1 and Mut6 exhibited larger depressions in ALS activity at 6 weeks than plants in the untreated area. Again, activity showed recovery at 12 weeks, mirroring that seen in the untreated area. This suggests that the slight depression for Mut1 and Mut6, and the continued decline in activity for control N12 in the untreated area may have been due to herbicide drift from the adjacent treated plots. Eberlein and Guttieri (1994) reported that amounts as small as $1 / 50$ th of the normal agricultural imazapyr rate reduced potato yields by two-thirds and Bond et al. (2006) showed that a simulated drift rate of only $8 \mathrm{~g}$ a.i. ha ${ }^{-1}$ could reduce rice yield by $40 \%$.

When sprayed with $624 \mathrm{~g}$ a.i. ha-1 imazapyr, ALS activities of Mut1 and Mut6 decreased significantly $(P<0.001)$ from weeks 1 to 6 (Figure 3c). However, at week 12, ALS activities of Mut1 and Mut6 plants were significantly higher $(P<$ 0.001 ) than that of control N12 (Figure 3c). The ALS activity of the N12 control plants was close to zero by week 6 , did not recover by week 12 and was always significantly lower $(P<0.001)$ than those of Mut1 and Mut6 (Figure 3c). By harvest, all N12 control plants sprayed with imazapyr had died.

No significant differences in yield components were found between mutants and N12 within the untreated field area in both the plant (Table 2) and the ratoon crops (Table 3). Also, \% fibre and \% sucrose were not different between mutants and the parent (Table 3). This suggests that the mutation breeding approach did not significantly alter the yield component characteristics of the mutants. Within the sprayed areas, final live stalk numbers and stalk height were 
significantly reduced in Mut2, Mut3 and in N12 (Table 2).

\section{Imazapyr resistance in plants arising from setts planted in treated soil}

In the sprayed half of plot D (1248 g a.i. ha-1 imazapyr 3 weeks prior to planting), germination was 7 - $73 \%$ of that of the same genotype in the untreated area. Although statistical analysis was not possible due to limited material, germination was higher in Mut1 (61\%), Mut4 (73\%) and Mut6 (61\%) than in the other genotypes (Table 4). By week 12, Mut1 and Mut6 were significantly taller $(P<0.001)$ than the other mutants and control N12 (Table 4). Mut1 and Mut6 were also the least stunted relative to the shoot lengths in the untreated section ( 75 and $66 \%$ of untreated length, respectively). Mut2, Mut3 and control N12 had severely stunted growth compared with their untreated counterparts and the other genotypes.

\section{Potential modes of herbicide resistance in the tested mutant plants}

Mut1, and perhaps Mut5, may have mutations in the als gene, conferring reduced inhibition of enzyme activity by imazapyr (increased IC ${ }_{50}$; Figure 1). To date, only one such mutation (Ala-559) in the als gene of sugarcane has been reported (Khruangchan et al. 2011). Other possible target site alterations could include increased ALS enzyme basal activity due to higher als gene transcript levels or gene copies (Boutsalis et al. 1999, Yu et al. 2003). Enhanced enzymatic activity is also possible due to post-transcriptional regulation, increased mRNA stability and/or reduced enzyme degradation (increased half-life) (Yuan et al. 2002). Mut1 and Mut6 showed 1.4-fold increase in basal ALS activities (Table 1). Overproduction of the target enzyme (per unit of protein or fresh weight) increases the number of

Table 2. Yield components and estimated yield of field-grown plants after 11 months. Two months after planting, imazapyr was applied (312 and $624 \mathrm{~g}$ a.i. ha $^{-1}$ ) to areas B and C; area A was untreated. a-d = statistical difference between each genotype

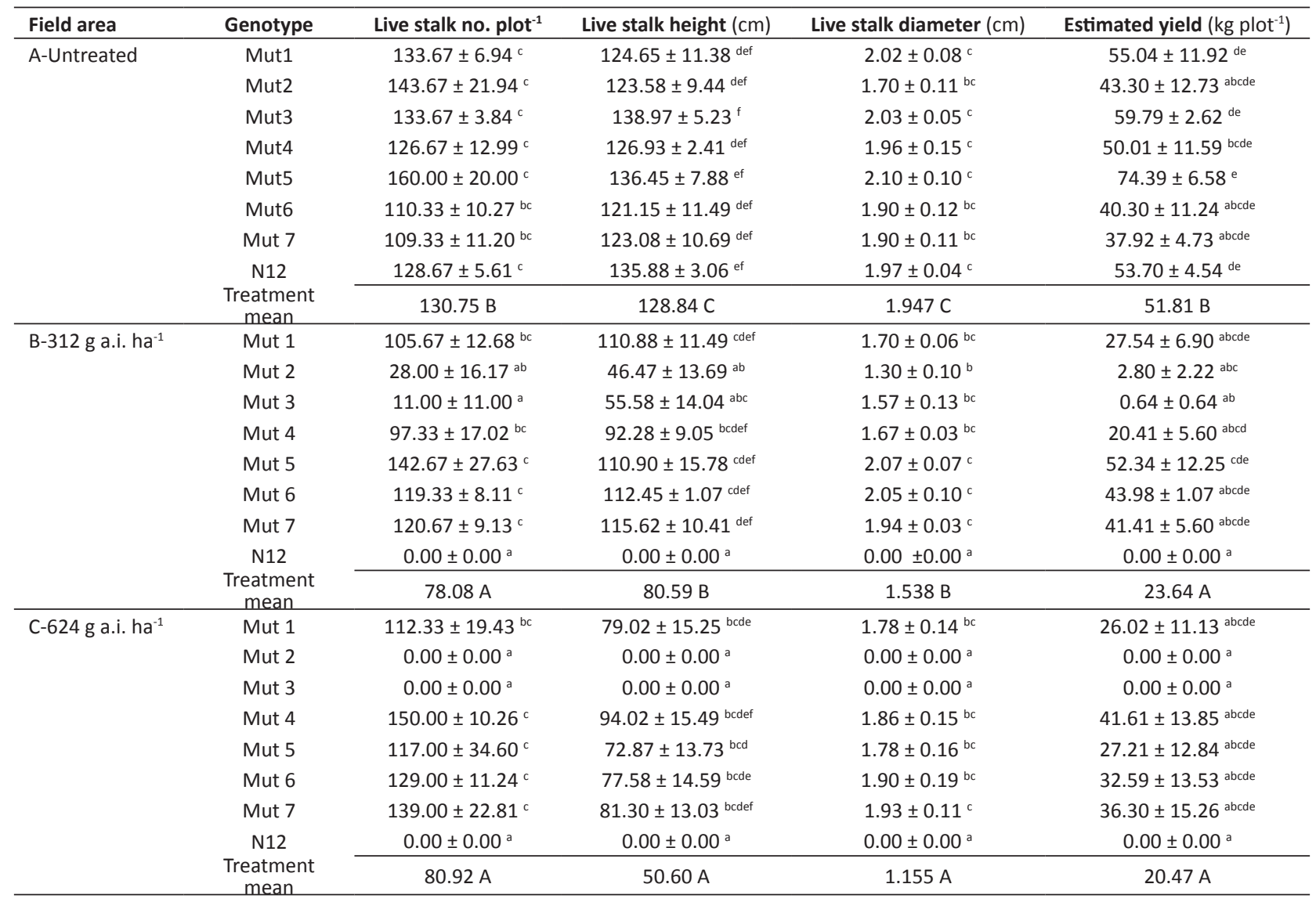

REML analysis and Holm-Sidak test, $P<0.05 ; \mathrm{n}=3 ;$ mean $\pm \mathrm{SE}$ 
target sites that must be inhibited in order to block amino acid synthesis, diluting the effect of the herbicide (Powles 2010). Alarcón-Reverte et al. (2015) characterized a glyphosate-resistant Echinochloa line that lacked known resistance, conferring mutations in the gene of the target enzyme 5-enolpyruvylshikimate-3-phosphate synthase (EPSPS), but they only sequenced part of the gene. That line was similar to susceptible ones in glyphosate absorption, translocation or metabolism, but had a 1.4-fold higher basal EPSPS activity and 5-fold higher LD $_{50}$ than susceptible plants when sprayed with glyphosate. Thus, it may be possible that the increased basal ALS activities seen in Mut1 and Mut6 contribute to their increased imazapyr resistance (Table 1).

Plants also become resistant to herbicides via non-target-site (NTS)-based resistance (Yuan et al. 2007). Non-targetsite resistance appears to be controlled by multiple genes, each providing partial quantitative effects, which is difficult to study (Délye 2013). Also, it comprises a range of mechanisms that act to minimize the amount of herbicide reaching the target site, e.g. structural barriers to penetration, physiological exclusion by active transporters and reduced herbicide translocation, and increased metabolic detoxification (Yuan et al. 2007, Powles and Yu 2010). These mechanisms are possible in Mut4 and Mut7, which did not exhibit increased ALS IC ${ }_{50}$ levels or increased ALS basal activity. Similar to Mut1, Mut5 and Mut6, Mut4 and Mut7 were significantly better than the control N12 in terms of stalk survival and height when sprayed with imazapyr (Table 2), and in \% germination and shoot height when planted in imazapyrtreated soil (Table 4). Reduced absorption through the cuticle or other physical barrier and reduced translocation are unlikely to be involved as imazapyr resistance was generated in callus cells (Koch et al. 2012). However, in phase I of detoxification, herbicide molecules are activated and functional groups are exposed to phase II conjugation enzymes, and often to oxidation by cytochrome P450 monooxygenases known to participate in IMI metabolism (Manabe et al. 2007). A reduction of herbicide resistance by the $P 450$ monooxygenase inhibitor piperonyl butoxide has been reported for ALS inhibitors in maize and sunflower (Breccia et al. 2012).

The commercial success of IMI resistant mutants (Clearfield ${ }^{\circ}$ ) is partially due to less stringent regulations for mutants than for genetically modified (GM) organisms (Tan et al. 2005), e.g. 'substantial equivalence' requires demonstration

Table 3. An assessment of quality and yield traits of the first ratoon crop of the mutated sugarcane genotypes (Mut1 - Mut7) and the commercial variety N12, for the field area not treated with imazapyr (area A)

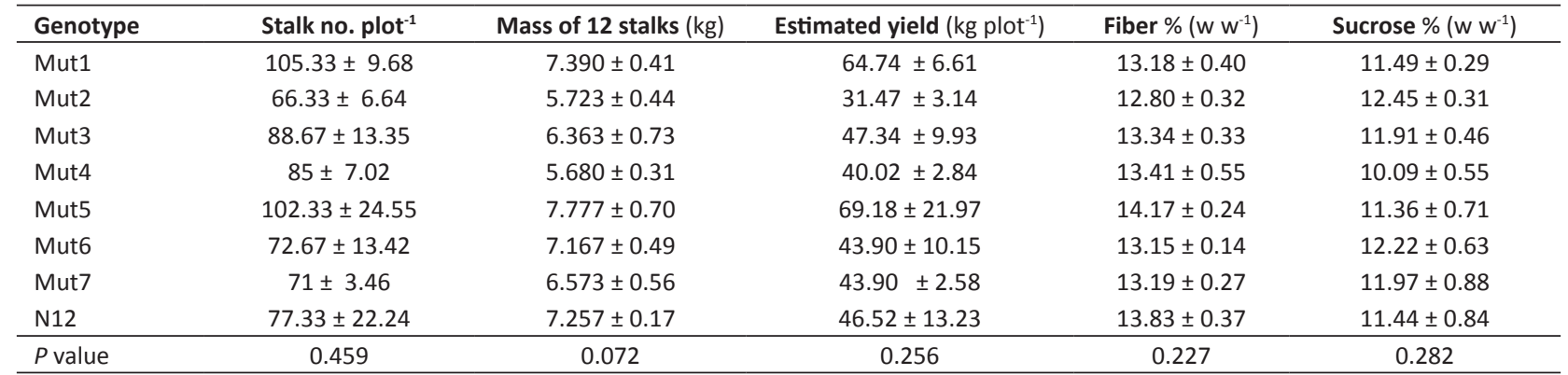

Data were analyzed using a One-Way ANOVA, $P<0.05, \mathrm{n}=3$, mean \pm SE. There were no statistically significant differences amongst mutant genotypes and N12.

Table 4. Germination and shoot length in the tested mutants (Mut1-Mut7) and the control N12. The soil in the treated section was sprayed with imazapyr (1248 g a.i. ha $\left.{ }^{-1}\right) 3$ weeks prior to planting. a-d denote a statistically significant difference between genotypes

\begin{tabular}{|c|c|c|c|}
\hline Genotype & $\begin{array}{c}\text { Germination after } \mathbf{3} \mathbf{w} \text { (as \% of that in } \\
\text { untreated section) }\end{array}$ & $\begin{array}{l}\text { Shoot length after } 12 \text { weeks (as \% of } \\
\text { shoot length in the untreated section) }\end{array}$ & $\begin{array}{l}\text { Shoot length }(\mathrm{mm}) \text { after } 12 \mathrm{w} \text { of geno- } \\
\text { types in the treated section }\end{array}$ \\
\hline Mut1 & 61 & 75 & $185 \pm 8.8^{d}$ \\
\hline Mut2 & 27 & 20 & $43 \pm 3.6^{a}$ \\
\hline Mut3 & 38 & 25 & $60 \pm 6.5^{a b}$ \\
\hline Mut4 & 73 & 44 & $115 \pm 5.2^{c}$ \\
\hline Mut5 & 48 & 34 & $88 \pm 2.7^{b c}$ \\
\hline Mut6 & 61 & 66 & $179 \pm 8.4^{d}$ \\
\hline Mut7 & 39 & 45 & $124 \pm 13.5^{c}$ \\
\hline N12 & 7 & 16 & $42 \pm 5.5^{\mathrm{a}}$ \\
\hline
\end{tabular}

One-way ANOVA and Holm-Sidak test, $P<0.001 ; \mathrm{n}=10$, mean $\pm \mathrm{SE}$ 
that the GM and the non-GM wild-type lines are similar, except for the transgene (Cellini et al. 2004). However, mutation breeding might cause unintended pleiotropic phenotypes, due to mutation effects on more genes than only the desired one (Manabe et al. 2007). Equivalence between our imazapyr resistant lines and the parent cultivar is therefore being pursued. Thus far, no significant differences in yield and quality components have been identified in imazapyr-untreated lines (Tables 2 and 3). However, yield and quality effects due to mutations will have to be further studied across additional soil types and for an extended crop cycle.

When sprayed with imazapyr, or planted into imazapyr-treated soil, Mut2 and Mut3 are the least resistant (Tables 2, 3 and 4). However, some stalk survival to maturity at the low foliar imazapyr dose (Table 2) and possibly a higher germination rate than that of the control N12 in treated soil (Table 4) in Mut2 and Mut3 indicate a low level resistance to imazapyr by these mutants. Mut2 and Mut3 could be considered 'escapes' from the in vitro selection protocol. A more stringent in vitro selection protocol could be used in the future to increase the likelihood of obtaining mutants with greater levels of resistance, such as those seen in Clearfield ${ }^{\circ}$ rice cultivars (Avila et al. 2005).

\section{CONCLUSIONS}

Five of the seven mutants tested showed greater imazapyr-resistance in the field than the control N12. Two had a 1.4-fold increase in basal ALS activity. Multiple resistance mechanisms seem to be present across the tested mutants, e.g. point mutations in the als gene, increased basal expression, and may include exclusion by transporters and increased detoxification, elements which are being investigated. The demonstrated ability to plant setts of the mutant genotypes during the residual period of imazapyr in the soil will afford farmers improved weed control.

\section{ACKNOWLEDGEMENTS}

We thank the National Research Foundation of South Africa (Grants 85573 and 85414) and the University of KwaZulu-Natal for funding and Dr P Campbell, Ms N Sewpersad and the Technical Team of the South African Sugarcane Research Institute (SASRI) for assistance with technical support and field measurements.

\section{REFERENCES}

Alarcón-Reverte R, García A., Watson SB, Abdallah I, Sabaté S, Hernández MJ, Dayan FE and Fischer AJ (2015) Concerted action of target-site mutations and high EPSPS activity in glyphosate-resistant junglerice (Echinochloa colona) from California. Pest Management Science 71: 996-1007.

Avila LA, Lee DJ, Senseman SA, McCauley GN, Chandler JM and Cothren JT (2005) Assessment of acetolactate synthase (ALS) tolerance to imazethapyr in red rice ecotypes (Oryza spp) and imidazolinone tolerant/ resistant rice (Oryza sativa) varieties. Pest Management Science 61: 171-178.

Bond JA, Griffin JL, Ellis JM, Linscombe SD and Williams BJ (2006) Corn and rice response to simulated drift of imazethapyr and imazapyr. Weed Technology 20: 113-117.

Boutsalis P, Karotam J and Powles SB (1999) Molecular basis of resistance to acetolactate synthase-inhibiting herbicides in Sisymbrium orientale and Brassica tournefortii. Pesticide Science 55: 507-516.

Bradford MM (1976) A rapid and sensitive method for the quantification of microgram quantities of protein utilizing the principle of proteindye binding. Analytical Biochemistry 72: 248-254.

Breccia G, Gil M, Vega T, Zorzoli R, Picardi L and Nestares G (2012) Effect of cytochrome P450s inhibitors on imidazolinone resistance in sunflower. Proceedings of the 18th Sunflower Conference, Mar del
Plata-Balcarce, Argentina, p. 507-512.

Campbell PL (2008) Efficacy of glyphosate, alternative post emergence herbicides and tillage for control of Cynodon dactylon. South African Journal of Plant and Soil 25: 220-228.

Cellini F, Chesson A, Colquhoun I, Constable A, Davies HV, Engel KH, Gatehouse AMR, Kärenlampi S, Kok EJ, Leguay J-J, Lehesranta S, Noteborn HPJM, Pedersen J and Smith M (2004) Unintended effects and their detection in genetically modified crops. Food and Chemical Toxicology 42: 1089-1125.

Cockburn JJ, Coetzee HC, Witthöft J, Conlong DE and Van Den Berg J (2012) Exploring the feasibility of push-pull for use in management of Eldana saccharina Walker (Lepidoptera, Pyralidae) by small-scale sugarcane growers. Proceedings of the South African Sugar Technologists' Association 85: 134.

Délye C (2013) Unravelling the genetic bases of non-target-site-based resistance (NTSR) to herbicides, a major challenge for weed science in the forthcoming decade. Pest Management Science 69: 176-187.

Eberlein CV and Guttieri MJ (1994) Potato (Solanum tuberosum) response to simulated drift of imidazolinone herbicides. Weed Science 42: 70-75.

Gravois KA, Milligan SB and Martin FA (1991) Indirect selection for increased sucrose yield in early sugarcane testing stages. Field Crops Research 26: 67-73. 
Khruangchan N, Chatchawankanphanich O and Pornprom T (2011) Acetolactate synthase gene mutation conferring imazapyr tolerance in sugarcane clone. Journal of the National Research Council of Thailand 41: 115-127.

Koch AC, Ramgareeb S, Rutherford RS, Snyman SJ and Watt PM (2012) An in vitro mutagenesis protocol for the production of sugarcane tolerant to the herbicide imazapyr. In vitro Cellular and Developmental Biology-Plant 48: 417-427.

Leibbrandt NB and Snyman SJ (2003) Stability of gene expression and agronomic performance of a transgenic herbicide-resistant sugarcane line in South Africa. Crop Science 43: 671-677.

Manabe Y, Tinker N, Colville A and Miki B (2007) CSR1, the sole target of imidazolinone herbicide in Arabidopsis thaliana. Plant Cell Physiology 48: $1340-1358$.

McIntyre RK and Nuss KJ (1998) An evaluation of the variety N12 in field trials. Proceedings of the South African Sugar Technologists' Association 72: 28-34.

Miller JD and James NI (1974) The influence of stalk density on cane yield. Proceedings of the International Society of Sugar Cane Technologists 15: $177-184$.

Millhollon RW (1992) Effect of itchgrass (Rottboellia cochinchinensis) interference on growth and yield of sugarcane (Saccharum spp. hybrids). Weed Science 40: 48-53.

Powles S (2010) Gene amplification delivers glyphosate-resistant weed evolution. Proceedings of the National Academy of Sciences USA 107: 955-956.

Powles S and Yu Q (2010) Evolution in action, plants resistant to herbicides. Annual Review of Plant Biology 61: 317-347.

Ramgareeb S, Snyman SJ, van Antwerpen T and Rutherford RS (2010) Elimination of virus and rapid propagation of disease-free sugarcane
(Saccharum spp. cultivar NCo376) using apical meristem culture. Plant Cell Tissue and Organ Culture 96: 263-271.

Rutherford RS, Snyman SJ and Watt MP (2014) In vitro studies on somaclonal variation and induced mutagenesis, progress and prospects in sugarcane (Saccharum spp.) - a review. Journal of Horticultural Science and Biotechnology 89: 1-16.

Santos L O, Pinto JJO, Piveta LB, Noldin J A Galon L and Concenço G (2014) Carryover effect of imidazolinone herbicides for crops following rice. American Journal of Plant Sciences 5: 1049-1058.

Schoonees-Muir BM, Ronaldson MA, Naidoo G and Schorn PM (2009) SASTA Laboratory Manual including the Official Methods. 5th Edition. ISBN 978-0-620-43586-4.

Tan S, Evans RR and Singh BK (2006) Herbicidal inhibitors of amino acid biosynthesis and herbicide-tolerant crops. Amino Acids 30: 195-204.

Tan S, Evans RR, Dahmer ML, Singh BK and Shaner DL (2005) Imidazolinonetolerant crops, history, current status and future. Pest Management Science 61: 246-257.

Yu Q, Han H, Vila-Aiub MM and Powles SB (2010) AHAS herbicide resistance endowing mutations, effect on AHAS functionality and plant growth. Journal of Experimental Botany 61: 3925-3934.

Yu Q, Zhang XQ, Hashem A, Walsh MJ and Powles SB (2003) ALS gene proline (197) mutations confer ALS herbicide resistance in eight separated wild radish (Raphanus raphanistrum) populations. Weed Science 51: 831-838.

Yuan Cl, Chaing M and Chen YM (2002) Triple mechanisms of glyphosateresistance in a naturally occurring glyphosate-resistant plant Dicliptera chinensis. Plant Science 163: 543-554.

Yuan JS, Tranel PJ and Stewart Jr CN (2007) Non-target-site herbicide resistance: a family business. Trends in Plant Sciences 12: 6-13. 